\title{
PRAKTIKALITAS BAHAN AJAR MATEMATIKA TERINTEGRASI NILAI ISLAM MENGGUNAKAN PENDEKATAN SAINTIFIK UNTUK PENGEMBANGAN KARAKTER PESERTA DIDIK
}

\author{
Nurhamdiah $^{1}$, Maimunah ${ }^{2}$, Yenita Roza ${ }^{3}$ \\ 1,2,3 Program Pasca Sarjana Pendidikan Matematika, Universitas Riau, Jl. H.R Soebrantas, Riau \\ Nurhamdiah6590@grad.unri.ac.id
}

\begin{abstract}
Character development of students becomes the main focus in the world of education. This is based on the facts about the decline of the character of the nation's children. This study aims to produce mathematics teaching materials integrated with Islamic values through a valid and practical scientific approach to develop students' character in the set material. This type of research is a research development using the ADDIE model. The instruments in this study were practicality sheets. The results of the practicality of teaching materials in field trials was $92.60 \%$ and teacher observations averaged $96.59 \%$. It can be concluded that the mathematics teaching material integrated with Islamic values uses a scientific approach that is developed valid and practical to develop the character of VII grade students of SMP / MTs.
\end{abstract}

Keywords: Teaching Material, Islamic Values, Scientific Approach, Character

\begin{abstract}
Abstrak
Pengembangan karakter peserta didik menjadi fokus utama dalam dunia pendidikan. Hal ini didasarkan pada fakta tentang menurunnya karakter anak bangsa. Penelitian ini bertujuan untuk menghasilkan bahan ajar matematika terintegrasi nilai Islam melalui pendekatan saintifik yang valid dan praktis untuk mengembangkan karakter peserta didik pada materi himpunan. Jenis penelitian yang digunakan adalah penelitian pengembangan menggunakan model ADDIE. Instrumen dalam penelitian ini adalah lembar praktikalitas yaitu angket respon peserta didik dan lembar pengamatan guru. Praktikalitas bahan ajar pada ujicoba lapangan adalah 92,60\% dan hasil pengamatan guru dengan rata-rata 96,59\%. Dapat disimpulkan bahwa bahan ajar matematika terintegrasi nilai islam menggunakan pendekatan saintifik yang dikembangkan praktis untuk mengembangkan karakter peserta didik kelas VII SMP/MTs.
\end{abstract}

Kata kunci: Bahan Ajar, Nilai Islam, Pendekatan Saintifik, Karakter

\section{PENDAHULUAN}

Karakter berkaitan dengan baik atau buruknya seseorang (Wahyudin,2013). Penerapan karakter dilingkungan masyarakat pada umumnya tidak lepas dari proses pembentukan manusia itu sendiri. Permasalahan yang sering terjadi yaitu hal-hal yang kurang pantas dilakukan oleh beberapa peserta didik. Banyak kasus penyimpangan nilai moral di kalangan peserta didik SMP/MTs seperti tidak patuh pada aturan kelas dan sekolah, bermain dan berbicara saat guru menjelaskan materi, berkata kasar atau tidak sopan dengan teman, hadir tidak tepat waktu dan tidak menyelesaikan tugas (Apriani dan Wangid, 2015). Berdasarkan hasil wawancara peneliti dengan beberapa guru di MTS dan SMP di Kota Pekanbaru mengenai karakter peserta didik, guru menyebutkan bahwa karakter peserta didik semakin hari semakin menurun. Peserta didik hampir setiap hari terlambat ke sekolah. Selain itu masih sering ditemukan peserta didik bermain dan berbicara dengan temannya ketika guru menjelaskan materi, dan masih banyak lagi hal-hal yang menyimpang yang menunjukkan karakter peserta didik yang semakin menurun. Selain bermasalah pada karakter, ternyata hasil belajar peserta didik juga bermasalah. 
Rendahnya hasil belajar dan menurunnya karakter peserta didik menunjukkan peserta didik sudah berada pada titik yang mengkhawatirkan. Dalam mengembalikan karakter positif diperlukan usaha yang menyeluruh dari semua pihak yaitu keluarga, masyarakat, dan sekolah (Sulistyowati, 2012, Majid dan Andayani, 2012).

Pembentukan karakter peserta didik sebenarnya sudah tertuang dalam fungsi dan tujuan pendidikan nasional dan Transformasi pendidikan nasional Indonesia yaitu adanya gerakan Penguatan Pendidikan Karakter (Vivi Pusputa, Asrina Mulyati, \& Didi Maielfi, 2019). Seiring dengan munculnya transformasi pendidikan nasional Indonesia, banyak peneliti yang menyatakan bahwa perlu adanya pengembangan karakter di sekolah. Pengembangan karakter di sekolah sangat dibutuhkan melihat kondisi para pelajar sekarang yang semakin hari nilai karakternya semakin menipis salah satunya dalam pembelajaran matematika (Kamaruddin, dkk., 2014, Salafudin, 2015, Anugraheni, 2018, Fauziyah dan Jailani, 2014).

Pembelajaran matematika tidak hanya dimaksudkan untuk mencerdaskan peserta didik, tetapi menghasilkan peserta didik berkepribadian kritis dan berkarakter baik (Suparni, 2012). Umi Khoiriyah dan Swaditya Rizky (2017) menyatakan bahwa dalam pelaksanaan pembelajaran terutama matematika diperlukannya perhatian dan prioritas dalam pembentukan karakter. Pembelajaran matematika tidak hanya menekankan aspek kognitif tetapi dalam pembelajaran matematika harus dapat membentuk karakter peserta didik (Sardjijo dan Hapzi Alif, 2017, Najib dan Ahadiyah, 2012, Kindangen, Runtu, dan Monoarfa 2017).

Adanya kesenjangan antara harapan dan kenyataan, maka penting untuk melakukan upaya dalam mengembangkan karakter. Salah satu upaya tersebut adalah dengan pemilihan dan penggunaan pendekatan pembelajaran yang tepat yang dapat mengembangkan karakter peserta didik. Kurikulum 2013 mengamanatkan esensi pendekatan ilmiah atau pendekatan saintifik dalam pembelajaran. Pendekatan saintifik mampu mengembangkan ranah sikap, keterampilan, dan pengetahuan peserta didik dengan tujuan mengembangkan good character (Sumayasa,dkk., 2015, Apriani, 2015).

Kaitannya dengan karakter, Pendidikan Islam dapat membentuk kepribadian berkarakter, berakhlak mulia dan beradab. Pendidikan yang terintegrasi nilai islam akan membentuk kepribadian yang baik. Integrasi nilai islam ke dalam kurikulum yakni bahan ajar, perangkat pembelajaran dan halhal yang berkaitan dengan proses pembelajaran berkontribusi menghasilkan manusia yang berkarakter baik, yang mengaplikasikan pengetahuannya sesuai dengan islam (Jamilah, Najib, Dzulkhairi, Ariff, dan Ismail, 2014). Nilai islam dapat diintegrasikan dalam proses pembelajaran matematika sehingga dapat mengantarkan peserta didik untuk mencapai pengetahuan, pemahaman, dan penerapan nilai islam (Mulia Diana, dkk., 2018). Soleha dan Rada (2011) menyatakan bahwa nilai-nilai islam dapat menanamkan dan membentuk sikap hidup juga mengembangkan kemampuan berilmu pengetahuan.

Kenyataannya pembelajaran matematika lazimnya dilakukan secara parsial, bukan merupakan bagian yang terintegrasi dengan mata pelajaran lain, termasuk dengan Pendidikan Agama Islam (Salafudin, 2015). Oleh sebab itu diperlukan suatu rumusan pembelajaran matematika yang 
mengintegrasikan nilai islam pada topik-topik matematika sekolah (Kohar, 2012). Pengintegrasian nilai islam dalam matematika seharusnya dilakukan secara menyeluruh pada materi matematika di seluruh jenjang pendidikan (Kurniati, 2015, Mohd Amin, Yusof, \& Haneef, 2010). Susilowati (2017) mengemukakan bahwa matematika terintegrasi nilai islam memungkinkan bahan ajar matematika diintegrasi dengan teori agama sehingga terbangun teori yang kuat, saling melengkapi, dan mengkonfirmasi.

Nilai Islam merupakan nilai yang bersumber dari Al Qur'an dan Hadits. Nilai islam merupakan landasan yang kuat bagi umat islam untuk mengggapai kebahagiaan dalam hidup. Adapun indicator nilai islam yang diintegrasikan ke dalam bahan ajar adalah 1) selalu menyebut nama Allah SWT, 2) penelusuran sejarah, 3) penggunaan isitilah yang bernuansa islam, 4) visualisasi ilustrasi yaitu gambargambar yang dinuansai islam.

Menurut Hamalik (2011) bahan ajar adalah bagian dari kurikulum dalam program pengajaran, yang berisi materi-materi sehingga memiliki arah dan tujuan pembelajaran yang jelas. Sedangkan mneurut Amri dan Ahmadi (2010) bahan ajar yaitu segalan bentuk bahan yang digunakan dalam membantu guru melaksanakan kegiatan belajar mengajar. Berdasarkan pendapat para hali tersebur dapan disimpulkan bahwa bahan ajar adalah perangkat pembelajaran yang berisi materi yang tersusun secara sistematis, dan sesuai dengan kompetensi yang akan dicapai. Bahan ajar matematika yang terintegrasi nilai islam adalah salah satu jalan untuk mengatasi permasalahan yang terjadi, sehingga peserta didik tidak berifikir bahwa matematika hanya tentang angka dan rumus tetapi ada nilai islam yang terkandung didalamnya. Bahan ajar yang dikembangkan memuat materi himpunan.

Praktikalitas bahan ajar artinya bahan ajar yang dihasilkan dapat dimengerti oleh peserta didik (Sugiyono, 2012). Bahan ajar yang telah dikembangkan dikatakan praktis jika para ahli dan praktisi menyatakan bahwa secara teoritis bahwa bahan ajar tersebut dapat diterapkan di lapangan dan tingkat keterlaksanaannya termasuk dalam kategori baik (Rochmad, 2012). Tanda kepraktisan dari suatu bahan ajar cetak yaitu dapat dengan mudah digunakan dalam proses belajar mengajar oleh guru dan peserta didik (Andromed, 2018). Menurut Ahmad Fauzan (2013) dan Zhang Q., (2013) komponen praktikalitas dilihat pada aspek beberapa aspek yaitu mudah digunakan oleh peserta didik, produk membuat peserta didik lebih paham, kemenarikan produk, proses selama pembelajaran berlangsung dengan baik (evaluasi), dan model (pendekatan) yang digunakan.

Berdasarkan hasil wawancara yang peneliti lakukan dengan guru matematika di beberapa SMP dan MTs di Kota Pekanbaru mengenai bahan ajar yang digunakan, guru masih menggunakan bahan ajar yang disediakan pemerintah (sekolah) dan penerbit buku swasta serta dilengkapi dengan sumber lain yang disusun oleh tim musyawarah guru mata pelajaran (MGMP) matematika. Sumber belajar tersebut sebenarnya sudah memuatkan konsep-konsep matematika, namun masih belum memuat nilai islam. Guru kesulitan medapatkan bahan ajar matematika yang terintegrasi nilai-nilai islam. Selain tidak terintegrasi nilai islam, bahan ajar yang digunakan oleh peserta didik juga belum memuat penekanan pada pengembangan karakter. 
Berdasarkan masalah yang peneliti uraikan, maka tujuan penelitian ini adalah untuk mengembangkan bahan ajar matematika terintegrasi nilai islam melalui pendekatan saintifik materi himpunan yang valid, praktis, dan efektif untuk mengembangkan karakter peserta didik. Adapun karakter yang dimaksudkan dalam penelitian ini adalah karakter yang dipadukan dari kompetensi inti 1 dan kompetensi inti 2 yaitu religius, jujur, disiplin, tanggung jawab, dan teliti.

\section{METODE}

Jenis penelitian yang digunakan dalam penelitian ini adalah penelitian pengembangan (Research and Development/ $R \& D$ ). Model pengembangan yang digunakan adalah ADDIE yaitu analyse, design, development, implementation, dan evaluation. Penelitian ini merupakan uji lanjutan pada tahp development (pengembangan), yaitu uji praktikalitas. Subjek uji coba dalam penelitian ini adalah terbagi dua yaitu subjek uji coba keterbacaan bahan ajar adalah Sembilan peserta didi kelas VIIIA SMP IT Ibnu Qoyyim dan subjek uji coba pada kelompok besar adalah 27 peserta didik kelas VII.A SMP IT Ibnu Qoyyim Pekanbaru selama 12 jam pelajaran atau sebanyak enam kali pertemuan.

Instrument praktikalitas yang digunakan adalah angket respon peserta didik dan lembar pengamatan aktivitas guru. Lembar pengamatan guru disesuaikan dengan rencana pelaksanaan pembelajaran yang disusun oleh peneliti dengan menggunakan pendekatan saintifik. Lembar pengamatan aktivitas guru digunakan untuk memperoleh data pengamatan keterlaksanaan yang berhubungan dengan penggunaan bahan ajar bagi guru dalam melaksanakan pembelajaran. Pengumpulan data yang digunakan adalah lembar observasi dan angket. Analisis data dalam penelitian ini yaitu analisis data kuantitatif dan analisis data kualitatif. Analisis hasil uji praktikalitas bahan ajar yang dikembangkan dilakukan dengan beberapa langkah, yaitu memberikan skor jawaban kriteria Sangat Baik (5), Baik (skor 4), Cukup Baik (skor 3), Kurang Baik (skor 2), Tidak Baik (skor 1); nilai persentase dengan rumus:

Tingkat praktikalitas $=\frac{\text { skor diperoleh }}{\text { skor maksimal }} \times 100 \%$

Kemudian data lembar pengamatan guru dan angket respon peserta didik diinterpretasikan berdasarkan tabel 1:

Tabel 1.

Interpretasi Data Praktikalitas Bahan Ajar Terintegrasi Nilai Islam Menggunakan Pendekatan Saintifik.

\begin{tabular}{cc}
\hline Interval & Kriteria \\
\hline $81 \%-100 \%$ & Sangat Praktis \\
\hline $61 \%-80 \%$ & Praktis \\
\hline $41 \%-60 \%$ & Cukup Praktis \\
\hline $21 \%-40 \%$ & Kurang Praktis \\
\hline $0 \%-20 \%$ & Tidak Praktis \\
\hline
\end{tabular}

Sumber:Modifikasi dari Riduwan (2012) 
HASIL

Penelitian ini dilakukan sesuai prosedur pengembangan ADDIE. Pada tahap analysis dilakukan analisis bahan ajar yang digunakan peserta didik, analisis materi, dan analisis peserta didik. Berdasarkan hasil wawancara dan studi dokumen sumber belajar yang digunakan peserta didik dalam pembelajaran matematika adalah LKS yang dibeli sekolah kepada penerbit. LKS matematika tersebut berisi materi ringkas dan soal latihan yang belum terdapat integrasi keilmuannya. Materi matematika yang dianalisis adalah KD 3.4 dan 4.4 yaitu pada materi himpunan, sedangkan materi pendidikan agama islam yang dianalisis yaitu materi yang terdapat pada buku Al Qur'an Hadits, akidah Akhlak, Fiqh, dan Sejarah Kebudayaan Islam. Indicator nilai islam yang digunakan adalah penyebutan nama Allah SWT, penelusuran sejarah, penggunaan istilah yang bernuansa islam, dan visualisasi ilustrasi atau gambargambar yang disajikan sesuai dengan potret islam. Karakter yang dikembangkan adalah karakter religius, jujur, disiplin, tanggung jawab, dan teliti.

Berdasarkan angket yang disebarkan kepada sembilan peserta didik lima diantaranya menganggap bahan ajar yang dimilikinya sangat sulit untuk dipahami, dua peserta didik menganggap biasa saja, dan dua peserta didik menganggap bahan ajar yang digunakan sangat mudah dipahami. Berkaitan dengan tempat yang sering digunakan peserta didik dalam mengulang pelajaran, tujuh dari Sembilan peserta didik lebih sering mengulang pelajaran di rumah. Mengenai peran bahan ajar bagi peserta didik, enam dari sembilan peserta didik memandang peranan bahan ajar sangat penting. Sedangkan mengenai cara belajar peserta didik, $33,33 \%$ peserta didik lebih suka menghafal dan $66,66 \%$ lebih suka memahami.

Tahap design dilakukan dengan merancang bahan ajar matematika mengintegrasikan nilai Islam melalui pendekatan saintifik serta komponen-komponen yang berkaitan dengan bahan ajar tersebut. Pada tahap design yaitu mendesain cover bahan ajar yang mencerminkan nilai-nilai Islam, peta konsep, daftar isi, dan format penyajian materi. Setelah melalui tahap desain, selanjutnya bahan ajar yang dikembangkan di validasi oleh validator yang terdiri dari tiga orang dosen pendidikan matematika divalidasi dengan menggunakan angket yaitu ahli teknologi pendidikan dan ahli materi pembelajaran. Validator yang terlibat dalam penelitian ini adalah tiga dosen pendidikan matematika.

Setelah bahan ajar yang dikembangkan dinyatakan valid oleh validator, selanjutnya bahan ajar diujicobakan. Uji coba keterbacaan bahan ajar kelompok kecil dilakukan kepada sembilan peserta didik kelas VIII SMPIT Ibnu Qoyyim Kota Pekanbaru. Setelah dilakukan uji coba keterbacaan bahan ajar, peneliti kemudian melakukan perbaikan sesuai saran yang diberikan peserta didik. Setelah bahan ajar diperbaiki, bahan ajar kemudian diuji cobakan kelompok kecil yaitu 15 peserta didik kelas VII SMPIT Ibnu Qoyyim Kota Pekanbaru. Adapun persesntase hasil angket respon peserta didik pada uji coba kelompok kecil terdapat pada tabel 2. 


\section{Tabel 2.}

Hasil angket respon peserta didik uji coba kelompok kecil

\begin{tabular}{|c|l|l|l|}
\hline No & \multicolumn{1}{|c|}{ Aspek } & \multicolumn{1}{c|}{ Rata-rata } & \multicolumn{1}{c|}{ Kategori } \\
\hline 1 & Tampilan bahan ajar & 85,08 & Sangat Praktis \\
\hline 2 & Proses penggunaan & 86,70 & Sangat Praktis \\
\hline 3 & Integrasi nilai silam dan pendekatan saintifik & 90,00 & Sangat Praktis \\
\hline 4 & Evaluasi & 90,89 & Sangat Praktis \\
\hline \multicolumn{2}{|c|}{ Rata- rata Keseluruhan } & 88,20 & Sangat Praktis \\
\hline
\end{tabular}

Tabel 2 jelas terlihat bahwa persentase keseluruhan dari penilaian oleh peserta didik adalah "sangat praktis", bahan ajar tidak memerlukan revisi yang berat. Namun komentar dan saran dari peserta didik dijadikan sebagai bahan perbaikan untuk penyempurnaan bahan ajar ini sebelum melakukan uji coba kelompok besar. Setelah bahan ajar direvisi, selanjutnya dilakukan uji coba kelompok besar terhadap satu kelas yang terdiri dari 27 orang peserta didik. Uji coba kelompok terbatas ini dilakukan kepada peserta didik kelas VII.B SMPIT Ibnu Qoyyim. Penelitian ini dilakukan di dalam kelas selama enam kali pertemuan.

Hasil penilaian uji praktikalitas pada saat uji coba dipaparkan dalam tabel 3 berikut:

\section{Tabel 3.}

Hasil angket respon peserta didik uji coba kelompok kecil

\begin{tabular}{|c|l|l|l|}
\hline No & \multicolumn{1}{|c|}{ Aspek } & \multicolumn{1}{c|}{ Rata-rata } & \multicolumn{1}{c|}{ Kategori } \\
\hline 1 & Tampilan bahan ajar & 92,57 & Sangat Praktis \\
\hline 2 & Proses penggunaan & 91,00 & Sangat Praktis \\
\hline 3 & Integrasi nilai Islam dan pendekatan saintifik & 94,00 & Sangat Praktis \\
\hline 4 & Evaluasi & 92,80 & Sangat Praktis \\
\hline \multicolumn{2}{r|}{ Rata- rata Keseluruhan } & 92,60 & Sangat Praktis \\
\hline
\end{tabular}

Berdasarkan tabel 3 jelas terlihat bahwa persentase keseluruhan dari penilaian oleh peserta didik adalah "sangat praktis". Data keseluruhan dari uji praktikalitas kelompok kecil dan kelompok terbatas yang telah didapatkan kemudian dijumlahkan dan dibagi dua, didapatkan bahwa tingkat kepraktisan bahan ajar matematika yang telah dikembangkan adalah $89,84 \%$ yang berarti bahan ajar matematika ini termasuk ke dalam kriteria "sangat praktis".

Lembar pengamatan keterlaksanaan pembelajaran dalam menggunakan bahan ajar dilaksanakan setiap kali proses pembelajaran berlangsung. Observasi keterlaksanaan dilakukan untuk mengetahui kepraktisan bahan ajar yang dikembangkan. Lembar pengamatan menilai beberapa aspek yaitu kegiatan pembuka, kegiatan inti dan kegiatan penutup pada proses pembelajaran. Adapun rata-rata keseluruhan dari lembar pengamatan guru terdapat pada tabel 2 . 


\section{Tabel 4.}

Persentase Lembar Pengamatan Guru

\begin{tabular}{|c|c|c|c|}
\hline $\begin{array}{c}\text { Aspek } \\
\text { Penilaian }\end{array}$ & Indikator Penilaian & $\begin{array}{l}\text { Rata-rata per- } \\
\text { Indikator }\end{array}$ & $\begin{array}{l}\text { Rata-rata } \\
\text { per- Aspek }\end{array}$ \\
\hline Kegiatan & Membaca do’a & $100 \%$ & \multirow{4}{*}{$96,87 \%$} \\
\hline \multirow{3}{*}{ Pembuka } & Menyampaikan tujuan pembelajaran & $100 \%$ & \\
\hline & Menyampaikan motivasi & $91,67 \%$ & \\
\hline & Menyampaikan apersepsi & $95,83 \%$ & \\
\hline \multirow[t]{5}{*}{ Kegiatan Inti } & Mengamati & $91,67 \%$ & \multirow{5}{*}{$95,00 \%$} \\
\hline & Menanya & $95,83 \%$ & \\
\hline & Mengumpulkan informasi & $100 \%$ & \\
\hline & Mencoba dan menalar & $91,67 \%$ & \\
\hline & Mengkomunikasikan & $91,67 \%$ & \\
\hline \multirow{5}{*}{$\begin{array}{l}\text { Kegiatan } \\
\text { Penutup }\end{array}$} & Memberikan tes & $100 \%$ & \multirow{4}{*}{$97,91 \%$} \\
\hline & $\begin{array}{l}\text { Melakukan kegiatan tindak lanjut dan } \\
\text { pemberian tugas }\end{array}$ & $100 \%$ & \\
\hline & $\begin{array}{l}\text { Menginformasikan rencana kegiatan } \\
\text { pembelajaran }\end{array}$ & $91,67 \%$ & \\
\hline & Menutup pembelajaran & $100 \%$ & \\
\hline & Rata-rata Keseluruhan & & $96,59 \%$ \\
\hline
\end{tabular}

Sumber : Data hasil olahan peneliti

Pada Tabel 3 diperoleh rata-rata keseluruhan dari lembar pengamatan keterlaksanaan aktivitas pembelajaran adalah 96,59\%. Dapat disimpulkan bahwa lembar pengamatan aktivitas guru terhadap bahan ajar matematika terintegrasi nilai islam melalui pendekatan saintifik berada pada kategori sangat praktis.

Hasil kepraktisan bahan ajar matematika terintegrasi nilai islam dapat dilihat pada gambar 1.

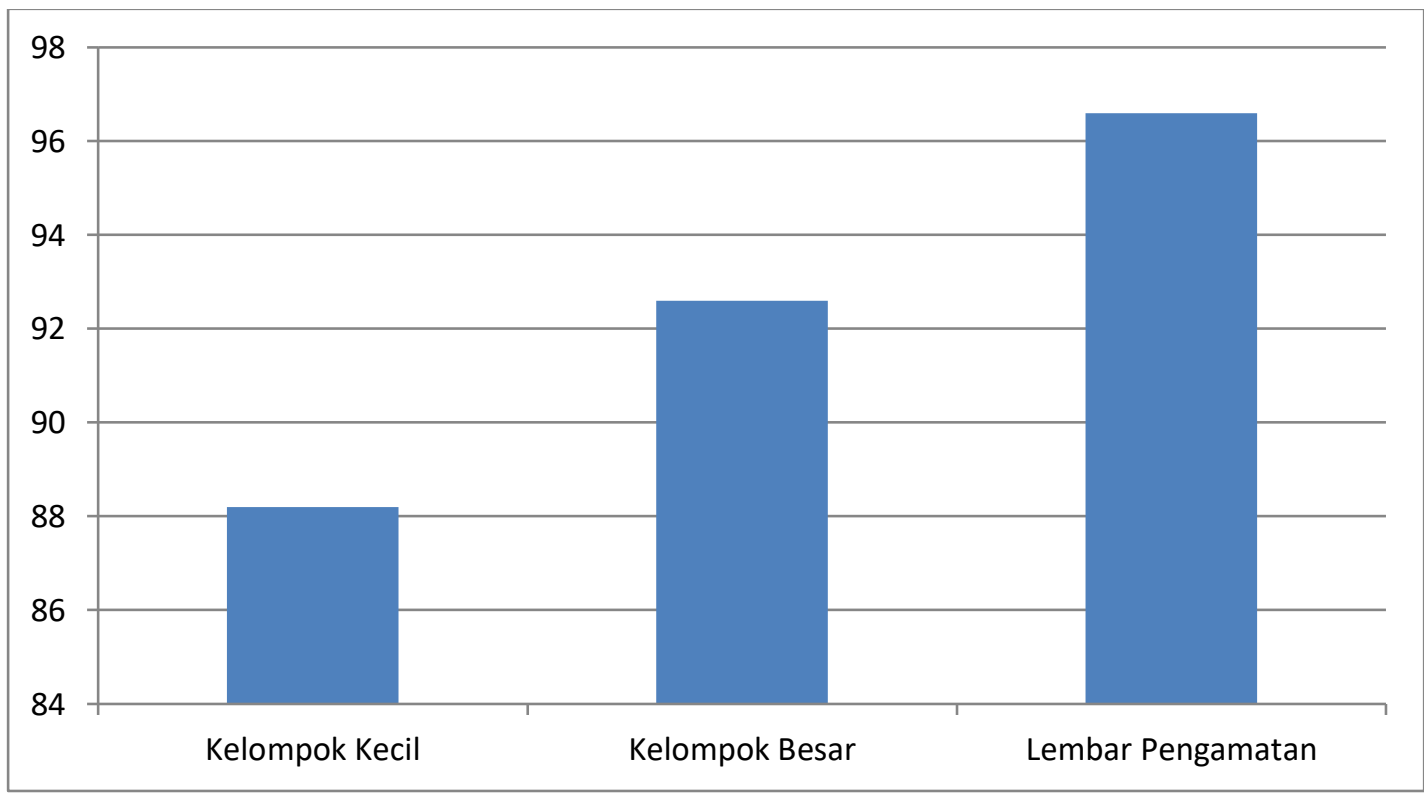

Gambar 1. Persentase kepraktisan bahan ajar

Gambar 1 menunjukkan kepraktisan bahan ajar matematika terintegrasi nilai Islam melalui pendekatan saintifik dilihat dari angket respon peserta didik pada uji coba kelompok kecil, kelompok besar, dan lembar pengamatan. Dapat disimpulkan bahwa bahan ajar matematika terintegrasi nilai Islam 
melalui pendekatan saintifik praktis untuk mengembangkan karakter peserta didik. Sejalan dengan penelitian yang dilakukan oleh Masduki (2015) tentang Integrating Islamic Veluees In Methematics Learning A Strategi Of Developing Student's Character menyebutkan bahwa salah satu strategi untuk mengembangkan karakter peserta didik yaitu dengan cara mengintegrasikan nilai islam ke dalam pembelajaran matematika. Penelitian yang dilakukan oleh Agus Setiawan (2016) tentang Pembelajaran matematika dasar berintegrasi keislaman untuk meningkatkan sikap religiusitas peserta didik menyebutkan bahwa sikap religiusitas peserta didik pada kelas eksperiman dominan dalam kategori baik. Penelitian yang dilakuakn Nur Indah Sari, Nawal Sartika Sari, Swaditya Rizki (2017) tentang Matematika dan Al Qur'an untuk membentuk pendidikan berkarakter Islami menyebutkan bahwa Matematika dan Al Qur'an dapat meningkatkan karakter Islami antara lain adalah kejujuran, kesabaran, kecermatan, dan ketelitian.

\section{KESIMPULAN}

Setelah dilakukan tahapan penelitian yaitu mulai dari anlisis, desain, pengembangan, implementasi, dan evaluasi. Dapat simpulkan bahwa bahan ajar matematika terintegrasi nilai islam melalui pendekatan saintifik sangat praktis, untuk mengembangkan karakter peserta didik. Berdasarkan hasil uji coba lapangan tingkat kepraktisan bahan ajar sebesar 89,84\% dengan kriteria sangat praktis, Dengan demikian bahan ajar yang dikembangkan dapat dijadikan sebagai bahan referensi dalam pelaksanaan pembelajaran. Adapun saran untuk pengembangan lebih lanjut adalah perlu penambahan soal mengenai nilai-nilai islam yang lebih luas, perlu mencari pengaruh dari mempelajari bahan ajar matematika yang dikembangkan.

\section{REFERENSI}

Apriani, A.-N., \& Wangid, M. N. (2015). Pengaruh SSP Tematik-Integratif Terhadap Karakter Disiplin Dan Tanggung Jawab Siswa Kelas III SD. Jurnal Prima Edukasia, 12-25.

Jamilah, J., Najib, A. A., Dzulkhairi, M., Ariff, H., \& Ismail, N. N. (2014). Integration Of Islamic Input In Medical Curriculum - Universiti Sains Islam Malaysia (USIM) Experience. The International Medical Journal Of Malaysia, 13(2), 73-77

Kamaruddin, R., Rahman, A., \& Djadir. (2014). Pengembangan Perangkat Pembelajaran Matematika Materi Geometri Berbasis Teori Belajar Van Hiele Untuk Mengembangkan Karakter Siswa Kelas VII1 SMP 2 Bulupoddo. Mapan : Jurnal Matematika Dan Pembelajaran, 2 (1), 63-74.

Kohar, Ahmad Wachidul. (2010). Makalah Seminar Pendidikan Matematika "Membumikan Pendidikan Nilai Melalui Integrasi Islam Dalam Pembelajaran Matematika”.FMIPA UNESA. Kurniati, A. (2015). Mengenalkan Matematika Terintegrasi Islam Kepada Anak Sejak Dini. Suska Journal Of Mathematics Education. 1(1): 1 -8. 
Layin Fauziyah, Jailani. (2014). Pengembangan Perangkat Pembelajaran Matematika Yang Menunjang Pendidikan Karakter Siswa Kelas IV Sekolah Dasar. Jurnal Prima Edukasia, Volume 2 - Nomor 2, Hal $149-163$.

Majid, A \& Andayani, D. (2012). Pendidikan Karakter Perspektif Islam. Bandung: PT. Remaja Rosdakarya.

Mohd Amin, R., Yusof, S. A., \& Haneef, M. A. (2010). The Effectiveness Of An Integrated Curriculum: The Case Of The International Islamic University Malaysia. In 8th International Conference On Islamic Economics And Finance (Pp. 1-20).

Mulia Diana, Netriwati, Dan Fraulein Intan Suri. (2018). Modul Pembelajaran Matematika Bernuansa Islami Dengan Pendekatan Inkuiri. Desimal: Jurnal Matematika, Vol. 1, No.1, Hal. 7-13

Sardjijo Dan Hapzi Alif. (2017). Integrating Character Building Into Mathematics And Science Courses In Elementary School. International Journal Of Environmental \& Science Education 2017, Vol. 12, No. 6, Hal.1547-1552.

Soleha Dan Rada. (2011). Ilmu Pendidikan Islam. Alfabeta, Bandung.

Salafudin. (2015). Pembelajaran Matematika Yang Bermuatan Nilai Islam. Jurnal Penelitian, 12 (2), 223-243.

Sulistyowati. (2012). Implementasi Kurikulum Pendidikan Karakter. PT Citraaji Parama, Yogyakarta. Sumayasa, I. N., Marhaeni, A. A., \& Dantes, N. (2015). Pengaruh Impiementasi Pendekatan Saintifik Terhadap Motivasi Belajar Dan Hasil Belajar Bahasa Indonesia Pada Siswa Kelas VI Di Sekolah Dasar Se Gugus VI Kecamatan Abang, Karangasem. E- Journal Program Pascasarjana Universitas Pendidikan Ganesha, 5.

Suparni. (2012). Pengembangan Karakter Bangsa Melalui Integrasi Nilai Keislaman Dalam Pembelajaran Matematika. Prosiding Seminar Nasional Penelitian, Pendidikan, Dan Penerapan MIPA, Fakultas MIPA, Universitas Negeri Yogyakarta.

Umi Khoiriyah, Swaditya Rizki. (2017). Pengembangan Bahan Ajar Himpunan Matematika Dikaitkan Dengan Nilai-Nilai Islam. Aksioma, Jurnal Pendidikan Matematika FKIP Univ. Muhammadiyah Metro. Vol. 6, No. 3, Hal 312 - 322.

Vivi Puspita, Asrina Mulyati, \& Didi Maielfi. (2019). Implementasi Pendidikan Karakter Pada

Matakuliah Matematika Sekolah Dasar Menggunakan Model CTL. Jurnal Cendekia: Jurnal Pendidikan Matematika. Vol. 03, No. 02, PP 504-512.

Wahyudin. (2013). Building The Character Of Learning Mathematics Curriculum 2013, Journal Education UT Vol. 14 September No.2 2013. 